\title{
BRÁS CUBAS VIAJANTE
}

\author{
Regina Zilberman
}

RESUMO: Essay about the novel of Machado de Assis, Memórias póstumas de Brás Cubas, in which the Author affirms that the travel is one of its leitmotivs. Based on this premiss, the affinities between the book of Machado de Assis and novels like Viagens na minha terra, written by Almeida Garrett, from Portugal, are examined.

PALAVRAS-CHAVE: viagem, herói nacional, representação da nacionalidade, mundo subterrâneo, Inferno, demoníaco, epopéia. romance.

Tudo irá como se realmente visses jogar a partida entre pessoa e pessoa, ou mais claramente, entre Deus e o Diabo. Machado de Assis (1959a, p. 63)

Memórias póstumas de Brás Cubas, de Machado de Assis, constitui uma das poucas obras da ficção brasileira a dispor, já no século XIX, de uma história editorial própria. A edição original do texto apareceu no terceiro tomo do primeiro ano da Revista Brasileira, periódico então dirigido por Nicolau Midosi. O ano era 1880, e o romance tomou primeiramente a forma do folhetim, dividido em dezessete partes, espalhadas nos

Regina Zilberman é professora titular de Teoria da Literatura do Pós Graduação da PUCRS. 
exemplares publicados entre março e dezembro. $\mathrm{O}$ formato em livro não demorou: logo em janeiro de 1881, a obra era lançada pela Tipografia Nacional, com alterações em sua ordenação. Em 1896, foi a vez da editora mais prestigiada da época, a Garnier, publicar o relato, repetindo a dose em 1899, ano da última versão de Memórias póstumas de Brás Cubas que Machado conheceu em vida.

Na passagem do folhetim para o livro, ocorrida entre 1880 e 1881, o escritor procedeu a mudanças, como a introdução de um prólogo, chamado "Ao leitor", a que se seguiu a dedicatória ao "verme" que roeria as "frias carnes" (ASSIS, 1881, p. VII) do cadáver do protagonista.

O "Ao leitor", que abre o livro, é assinado por Brás Cubas himself que procura explicar as peculiaridades de sua obra. Escreve ele que acabou redigindo "uma obra diffusa", em que adotou "a fórma livre de um Sterne, de um Lamb, ou de um Maistre", a qual somou "algumas rabugens de pessimismo". (ASSIS, 1881, p. VII). Esse texto não se mantém idêntico na passagem para a edição de 1896: a menção a Charles Lamb desaparece, permanecendo as referências à "fórma livre de um Sterne, ou de um Xavier de Maistre", acompanhada das mesmas "rabugens de pessimismo." (ASSIS, 1896, p. IX)

É essa citação que Machado transcreve, quando, na quarta edição da obra, lançada em 1899, introduz um novo prólogo, antecedendo o já existente "Ao leitor". Nesse texto, que ele assina com seu nome, ao contrário do anterior, imputado à personagem, escreve, em resposta a observações que lhe teria feito o crítico Macedo Soares, segundo o qual o romance "recordava amigavelmente as Viagens na minha terra" (ASSIS, 1899, p. VII):

Assim se explicou o finado: "Trata-se de uma obra diffusa, na qual eu, Braz Cubas, se adoptei a fórma livre de um Sterne ou de um Xavier de Maistre, não sei se lhe mettí algumas rabugens de pessimismo." Toda essa gente viajou: Xavier de Maistre á roda do quarto, Garret na terra d'elle, Sterne na terra dos outros. De Braz Cubas se pode talver [sic] dizer que viajou á roda da vida. (ASSIS, 1899, p. VII-VIII)

Citando a personagem fruto de sua imaginação, Machado reduplica seu discurso; e usa o motivo da viagem para justificar a presença de autores como Sterne, Maistre e Almeida Garrett como base de sua criação. Considerando que Brás Cubas é figura estabelecida no Rio de Janeiro por boa parte de sua vida, excluído o período em que, na juventude, estudou em Portugal e passeou pela Europa, a justificativa pode parecer paradoxal. Cabe, pois, verificar se e como o tema da viagem está presente em suas Memórias póstumas, examinando sua possível significação.

O tema da viagem é um dos mais persistentes da história da litera- 
tura ocidental. Walter Benjamin, no ensaio dedicado ao narrador, considera o viajante e, particularmente, o marinheiro responsável por uma das formas básicas de narrar, o que eleva a viagem à condição de motivo primordial da literatura:

A experiência que passa de pessoa a pessoa é a fonte a que recorreram todos os narradores. (...) Existem dois grupos, que se interpenetram de múltiplas maneiras. (...) Se quisermos concretizar esses dois grupos através de seus representantes arcaicos, podemos dizer que um é exemplificado pelo camponês sedentário, e outro pelo marinheiro comerciante. Na realidade, esses dois estilos de vida produziram de certo modo suas respectivas famílias de narradores. (...) A extensão real do reino narrativo, em todo o seu alcance histórico, só pode ser compreendida se levarmos em conta a interpenetração desses dois tipos arcaicos. (BENJAMIN, 1985, p. 198-199)

Exemplos desse tipo de narração remontam à Antigüidade. A Odisséia, provavelmente do século VIII a. C., consagra metade da intriga às andanças de Ulisses pelos mares, na tentativa de retornar à casa. Gilgamesh, epopéia mesopotâmica cuja primeira redação data do final do segundo milênio antes de Cristo, e cuja forma conhecida é contemporânea aos poemas de Homero, concentra seu episódio mais importante na busca, por parte do herói, da imortalidade, que encontra no fundo das águas e que depois, cansado, perde de modo pueril.

Viagens significam deslocamento no espaço, e sua visualização mais simples e usual é resumida pela linha horizontal. Mas podem tomar configuração vertical: Ulisses desce aos infernos, Gilgamesh, ao fundo do mar. Na História verdadeira, em que Luciano, no século II, parodia a Odisséia, de Homero, e os Argonautas, de Apolônio de Rodes, contam-se episódios ocorridos na Lua e nos Campos Elíseos, num permanente desafio à força da gravidade e às possibilidades de trânsito entre o alto e o baixo.

As viagens que foram matéria das obras de Laurence Sterne (Viagem sentimental e Tristam Shandy), Xavier de Maistre (Viagem à roda de meu quarto) e Almeida Garrett (Viagens na minha terra), mencionadas por Machado e relatadas em textos bem mais recentes que os acima citados, são horizontais e realistas: Sterne, em Viagem sentimental, narra suas peripécias na Europa continental, representando a passagem de um inglês, habitante da ilha britânica, para a terra firme, situada na França e, depois, na Itália; Almeida Garrett, circulando pelo interior de Portugal, faz o caminho contrário: revela seu país para si mesmo e para os outros, afinando a literatura nacional à estética romântica, que se evidenciava desde a valorização da cor local.

O livro de Maistre é o menos verista dos três: o narrador, 
enclausurado por 42 dias em seu próprio quarto, reporta o que transcorre nesse período, em que o espaço reduzido onde se encontra constitui todo o horizonte que detém. O relato toma coloração de sonho, e o narrador aparentemente passa por uma perturbação mental temporária. Num cotejo direto, esse texto parece ser o mais próximo do de Machado de Assis: ambos os narradores acham-se encerrados num espaço fechado e intransponível, deliram e produzem enunciados que beiram o discurso onírico.

O que menos relações parece guardar com o relato de Brás Cubas é o de Sterne, se pensamos em Viagem sentimental, talvez porque as principais associações entre esse ficcionista e Machado estabelecem-se a partir do interesse do brasileiro pelo instigante Tristam Shandy, obra plena de inovações gráficas e técnicas que se reproduzem, ainda que de modo atenuado, em Memórias póstumas. Não se podem ignorar, por sua vez, as aproximações com Viagens na minha terra, cujo autor, Almeida Garrett, constituiu uma admiração permanente de Machado de Assis. ${ }^{1}$

Viagens na minha terra é obra escrita à sombra da mais importante epopéia em língua portuguesa, Os Lusíadas, enquanto o avesso e o direito do poema épico. Tal como na obra de Luís de Camões, uma viagem de barco é realizada, mas o narrador de Almeida Garrett adentra-se no território português, enquanto que os descobridores avançam pelo mar. Vasco da Gama desloca-se no espaço, mas a trajetória dos navegantes é pretexto para a recuperação do passado português, cuja história é definida pelo poeta, valendo-se de informações fixadas sobretudo pelos cronistas medievais. Igualmente o narrador das Viagens na minha terra cruza o tempo, para verificar, contudo, as diferenças entre o passado e o presente, o antigo império e a decadência de sua época. Para não deixar dúvidas quanto a essas associações, Almeida Garrett introduz Os Lusíadas em sua obra, fazendo que a leitura da epopéia de Camões tanto emule o sentimento patriótico do leitor/escritor que narra o texto, quanto estimule a percepção das mudanças no tempo, levando à verificação da ruína atual:

(...) Peguei no Camões e fui para a janela. (...) Abri os Lusíadas à ventura, deparei com o canto IV e pus-me a ler aquelas belíssimas estâncias:

E já no porto da ínclita Ulisséia...

Pouco a pouco amotinou-se-me o sangue, senti baterem-me as artérias da fonte... as letras fugiam-me do livro, levantei os olhos com eles na pobre nau Vasco da Gama que aí está em

${ }^{1}$ Que declarou em crônica publicada na Gazeta de Notícias, por ocasião das comemorações do centenário de nascimento do escritor português: no "dia 4 de fevereiro de 1799 , (...) a raça portuguesa deu de si o seu maior engenho depois de Camões." (ASSIS, 1959b. p. 254) 
monumento-caricatura da nossa glória naval... E eu não vi nada disso, vi o Tejo, vi a bandeira portuguesa flutuando com a brisa da manhã, a torre de Belém ao longe... e sonhei, sonhei que era português, que Portugal era outra vez Portugal. (GARRETT, 1965, p. 272)

A transposição do espaço para o tempo faculta a reconstrução da história, conforme um duplo percurso instaurado por epopéias cujo motivo principal é a viagem e que Camões segue, enquanto Garrett deforma. Com efeito, desde a Odisséia, narrativa do retorno à casa por Ulisses, os poemas épicos introduzem, em meio ao relato das travessias e proezas das figuras humanas, a reconstituição de episódios de importância histórica. Primeiramente Nestor e Menelau, depois o aedo Demódoco e, enfim, o próprio herói recuperam, pela memória e pela poesia, os acontecimentos relativos à queda de Tróia e ao destino dos generais gregos após a tomada da cidadela inimiga. Virgílio utiliza o mesmo expediente, abrindo o primeiro canto da Eneida com a expedição de Enéias em pleno mar, para, no seguinte, introduzir os eventos passados, narrados pelo protagonista à rainha Dido, e esclarecer como ele fora conduzido àquela situação; mais adiante, Virgílio apresenta uma inovação, embora igualmente prevista na Odisséia: relata o que virá depois, prognóstico que antecipa acontecimentos vindouros em relação ao ponto em que situa cronologicamente a narrativa, mas conhecidos do poeta, porque já registrados pela história.

Camões reproduz o procedimento: recapitula-se a história medieval portuguesa nos cantos III e IV; no último canto, Vasco da Gama conhece o destino das navegações lusitanas, acontecimentos colocados no futuro conforme sua perspectiva, mas já passados se observados desde a ótica do poeta que os redigiu.

A epopéia fundada no motivo da viagem encontrou um meio de introduzir o tempo e a história ao fluxo narrativo; Almeida Garrett não negou o paradigma épico, embora o tenha utilizado para chegar ao inverso de seu resultado eufórico. No mesmo sentido, o herói de seu romance, Carlos, reproduz e subverte o padrão épico conferido ao protagonista, sugerindo pistas ao brasileiro Machado de Assis. Afinal, o gênero igualmente estabeleceu um padrão de personagem, aquele que corporificaria a nacionalidade, apresentando-se como modelo a igualar.

$\mathrm{Na}$ obra de Homero, Odisséia, Ulisses não ocupa essa função, embora sua peregrinação conduza à redescoberta do caminho de casa, a Ítaca, de que é rei e senhor; suas aventuras implicam igualmente a recuperação do trono, em combate singular com os pretendentes à vaga, e a reconquista do amor da esposa fiel, Penélope. Virgílio, refazendo o percurso marítimo de Ulisses por meio de Enéias, explora as virtualidades do tema: o protagonista da Eneida é um exilado, cabendo-lhe reconstruir Tróia com 
o que resta da família, a saber, o pai, Anquises, que logo falece, e o filho, Ascânio, que o acompanha por todo o tempo. Entre o abandono das ruínas da cidade natal e o início da geração latina cujo ponto alto coincidirá com a fundação de Roma, Enéias quase cede aos encantos de Dido, desce aos Infernos e, como seu ancestral literário, Ulisses, precisa enfrentar e vencer o rival Turno, habilitando-se à mão de Lavínia, genitora da descendência italiana do herói troiano.

Enéias tem uma noção tão clara de sua tarefa, que não sente remorsos pelo fim trágico da rainha de Cartago; além disso, o reencontro com o pai, quando lhe compete descer aos Infernos, e a narrativa do triunfo de Roma reforçam a idéia de que tudo o que precisa fazer é deixar que se cumpra o destino que lhe coube. Eis por que, a partir dele, estabelece-se um protótipo de herói fundador, capaz de instalar uma civilização sem que interfiram sentimentos pessoais ou dúvidas existenciais. Vasco da Gama é recortado por sobre esse modelo, mas Camões vai além: o herói se despersonaliza a tal ponto, que se confunde com o grupo, perdendo características individuais. Mesmo que, como Ulisses e Enéias, seja assediado por belas mulheres, como a Tétis que o recebe na Ilha dos Amores, ele fica imune ao apelo da sexualidade. Ulisses, por exemplo, coabita com Circe e, depois, Calipso, escondendo de Penélope essas aventuras; Enéias rapidamente esquece a princesa troiana com que fora casado, alimenta a paixão de Dido e conquista Lavínia, formando com esta última o par real. Vasco da Gama, não: embora a sensualidade rodeie a permissiva Ilha dos Amores, o nauta português mantém-se incólume, razão do seu sucesso ao final das missões de que fora incumbido.

Heroísmo e mulheres: eis uma mistura que nem sempre dá certo, sendo que o primeiro se confirma, à medida em que o segundo desaparece. Mulheres perturbam, quando se encarrega o guerreiro de fundar uma pátria, ainda mais quando, para chegar a um resultado favorável, cabe-lhe singrar os mares, enfrentar distâncias, combater exércitos inimigos, mostrar-se superior aos rivais. Os notáveis Ulisses, Enéias e Vasco da Gama foram felizes na execução dessas tarefas, mas, pouco a pouco, foram limitando a participação das fêmeas nas suas vidas; quando elas interferem, o ofício acaba sendo parcial ou pessimamente executado.

Este é o caso de Carlos, em Viagens na minha terra. Numa obra que pretende, no âmbito do mundo moderno, ocupar o papel que $O s$ Lusíadas detiveram no período de formação da nação portuguesa, Carlos emerge como a figura paradigmática do herói nacional: ilustrado, membro da elite e aliado a grupos progressistas, ele assume compromissos inalienáveis, mas sucumbe ao cinismo e ao baronato por não ter conseguido dar conta de seus entreveros amorosos. A dubiedade e, até, mau-caratismo 
com que trata as apaixonadas (Laura, Georgina e Joaninha) sinalizam sua incapacidade tanto para o exercício do papel político que se espera dele, quanto para a definição do lugar que uma mulher deve ocupar em sua vida. O diagnóstico de Garrett é desalentador: Portugal está em ruínas, urge a formulação de um projeto revolucionário liderado pela elite esclarecida, mas esta, sintetizada em Carlos, não está preparada para o desempenho da função para a qual foi convocada.

Com isso, dessacraliza-se o motivo da viagem: a do narrador das Viagens conduz à revelação da decadência e da morte, que leva consigo os sonhos e os ideais de mudança e renovação; a de Carlos redunda em fuga, e não retorno e reconstrução. Almeida Garrett, obrando com os padrões românticos de valorização da natureza e do espaço nacional, relata igualmente o fim da utopia, talvez a que ele, como revolucionário nas décadas de 20 e 30 do século XIX e, depois, participante do governo, igualmente abraçou com entusiasmo juvenil.

Quando Machado de Assis reconhece a presença de Viagens na minha terra na elaboração das Memórias póstumas, talvez ele esteja englobando igualmente os temas vinculados à tópica da viagem, o principal deles relacionado às possibilidades de utilizá-lo para expressar o mito de fundação e de eleger um herói para sintetizar o protótipo da nacionalidade. Sobretudo porque Almeida Garrett, ao fazê-lo, navega pela contramão: o escritor português contradiz as esperanças contidas na epopéia clássica e desmente o projeto romântico, revelando seu fracasso. Machado de Assis adota o caminho de Almeida Garrett, mas, munido da "pena da galhofa e [d] a tinta da melancolia" (ASSIS, 1959, p. 9), prefere trabalhar sob a égide da paródia e da carnavalização.

Para tanto, cabia voltar à epopéia e explorar vieses deixados de lado por Garrett e também por Camões. Afinal, entre os deveres do herói, está o de descer aos Infernos e conhecer a própria sorte e a dos outros, bem como os destinos da nação, se for o caso. Ulisses inaugura a série, obrigando-se a baixar ao Hades, onde é recepcionado inicialmente por Tirésias, adivinho capaz de ver o passado e prever o futuro, depois por ex-companheiros das batalhas nos campos de Ílion, como Aquiles, Ajax e Agamemnon. Sabedor de que este recebeu a morte ao chegar em casa, por obra de Clitemnestra, esposa desagravada que se vinga do marido com a ajuda de Egisto, seu amante, Ulisses alcança a Ítaca disfarçado, modo como ocupa e recupera o palácio e a família.

Entre a descida de Ulisses e sua repetição por Enéias, na obra de Virgílio, outros heróis andaram pelo Hades. O mito de Orfeu precede o relato de Homero, sugerindo ser viável entrar e sair incólume do império 
subterrâneo dominado por Plutão $;^{2}$ sucede-o a narrativa das aventuras de Dioniso ou Baco, que descende ao mundo dos mortos para buscar um dramaturgo que reabilite a tragédia ática, em processo de decadência, matéria da comédia As rãs, de Aristófanes, encenada no século V a. C. O mito da caverna, imaginado por Platão e exposto no Livro VII, da República, do século IV a. C., lida igualmente com a oposição entre o underground, marcado pela ausência de luz, logo, de saber, e o ground, a que se chega pela via do conhecimento e da ascese espiritual.

Por isso, igualmente Enéias pode entrar e sair do Hades, tendo acesso à imagem de seu pai e, principalmente, ao seu destino, a que se liga o futuro de Roma e a grandeza dos latinos. A descida aos Infernos traz consigo o conhecimento e a história, matéria que foi deslocada por Camões: a Ilha dos Amores, onde Vasco da Gama contempla o sucesso da empresa imperialista de Portugal, substitui o Hades, até porque, com a consolidação do Cristianismo no mundo europeu, o Inferno tomou outra conotação, ignorada por gregos e romanos.

Com efeito, a teologia cristã conferiu ao Inferno importância que até então ele não detinha, compreendendo para os antigos o lugar para onde a alma - ou a sombra - dos mortos se dirigia, após o passamento. A ascensão do Cristianismo coincidiu com a expansão do pensamento expresso nos livros apócrifos da Bíblia, rejeitados pelos rabinos, mas de grande circulação entre os séculos II a. C. e I d. C. Textos como o Livro de Enoch consagravam boa parte da história narrada ao relato da origem dos demônios, resultantes da queda dos anjos, os revoltosos que rejeitaram o poder de Deus. O Cristianismo, embora herdasse parte do patrimônio hebraico e incorporasse idéias do pensamento platônico, precisou achar um lugar para o Mal, bem como um sujeito que o encarnasse, já que o assunto dispunha de popularidade antes desconhecida. A nova função foi atribuída a Satã, personagem secundária no Velho Testamento, mas que experimenta notável valorização no decurso da Idade Média. Senhor de várias denominações - Lúcifer, ainda no período romano, Belzebu, para Dante Alighieri, Mefistófeles, no século XVI, outra vez Satã, para o moderno John Milton - e de diferentes fisionomias, o demônio talvez constitua a criação mais importante e original da teologia proveniente dos padres da Igreja.

Foram, contudo, os poetas e os artistas plásticos que conferiram texto e imagem ao diabo: os pintores da Renascença italiana dedicaram-se à representação dos temas associados ao demônio, como a perda do para-

${ }^{2}$ A narração desse mito, contudo, teve de aguardar Ovídio, no século I d. C., autor das Metamorfoses, onde se encontra o relato da trajetória de Orfeu.

124 
íso, a queda dos anjos, o Juízo Final. ${ }^{3}$ Dante Alighieri e John Milton, o primeiro no contexto do catolicismo neolatino e o segundo no âmbito do mundo anglo-saxão, construíram as principais epopéias do Cristianismo, uma organizando o universo da vida pós-morte, catalogado em Inferno, Purgatório e Paraíso, a outra explicando a causa da expulsão do Jardim do Éden e a culpa eterna dos humanos.

O Inferno desenhado por Dante não contradiz substancialmente a figuração herdada da Antigüidade, a quem deseja voluntariamente filiarse, escolhendo como seu guia Virgílio, autor da Eneida. Assim como o herói desses versos, Enéias, o poeta que narra A divina Comédia desce ao Inferno para conhecer: é lá que encontra as principais personagens da história da Itália, passada e presente, cujo juízo é filtrado pelos valores da Igreja, a saber os pecados capitais, a venalidade, a concupisciência. Dante confere forma ao Inferno, em cujo centro inferior, como uma pirâmide invertida, coloca Lúcifer ou Belzebu, imperador do mundo subterrâneo e senhor de todo o Mal.

Depois de Dante, ficou difícil para os autores épicos lidarem com a relação entre descida ao Inferno e busca do conhecimento ou descoberta do futuro. Camões optou por transferi-lo para a Ilha dos Amores, espécie de Éden superior ao original, pois, no território de Vênus e Tétis, a sexualidade não foi abolida. John Milton considera-o terreno habitado por Satã e sua corte, inacessível ao homem e inabilitado para levar o indivíduo à acumulação de conhecimento. Machado de Assis, contudo, oferece alternativas ao tema, articulando-o à sua origem, a saber, sua relação com o tema da viagem e a proposta de constituição de um herói representativo da nacionalidade.

Afinal, Machado de Assis conhecia o debate relativo à representação da nacionalidade e até o abordou em mais de um estudo crítico. No de 1858, chamado "O passado, o presente e o futuro da literatura", acata a perspectiva corrente na época, irmanando-se aos críticos de Tomás Antônio Gonzaga (entre os quais, o próprio Garrett), que cobravam a ausência de cor local nas liras arcádicas do amoroso Dirceu:

Gonzaga, um dos mais líricos poetas da língua portuguesa, pintava cenas da Arcádia, na frase de Garrett, em vez de dar uma cor local às suas liras, em vez de dar-lhes um cunho puramente nacional. (ASSIS, 1958, V. III)

Anos mais tarde, em 1873, ao escrever o hoje mais conhecido "Literatura brasileira - Instinto de nacionalidade", ele parece ter mudado

${ }^{3}$ Cf. BLOOM, 1996; DELUMEAU, 1990; ELIADE, 1969; ISIDORO de Sevilha, 1951; LANGTON, 1951; LINK, 1998. 
de idéia, atribuindo "[à] juventude literária, sobretudo" (ASSIS, 1959b, p. 130 ) o fazer da exposição da natureza local um cavalo de batalha, circunstância que provoca, por exemplo, a desqualificação da obra de Gonzaga: "Admira-se-lhes o talento, mas não se lhes perdoa o cajado e a pastora, e nisto há mais erro que acerto." (ASSIS, 1959b, p. 130)

A discussão, portanto, não era indiferente a Machado de Assis, que, com Memórias póstumas de Brás Cubas, parece dar uma resposta literária à questão. A primeira providência do romancista foi escolher um herói capaz de narrar sua história depois de morto. De imediato, ele pertence ao mundo subterrâneo, o mesmo dos vermes que roem as "frias carnes do [s] eu cadáver"; assim, ele não desce ao mundo subterrâneo, mas se encontra nele desde o começo, ao qual baixou por ocasião do enterro, relatado no primeiro capítulo.

A segunda foi atribuir ao protagonista um prenome adequado, que sintetizasse a intenção de fazê-lo ocupar o papel de herói nacional; por isso, em Brás, reproduz-se a primeira sílaba do nome da pátria, Brasil. E Machado não fica apenas na alusão alegórica: recorre à convenção do romance histórico, de larga aceitação durante o Romantismo, situando as raízes do herói no período colonial, época de formação de sua família. Por sua vez, fiel ao princípio desmitificador que embasa a escrita do livro, denuncia que a origem discutível e plebléia dos Cubas acabou sendo mascarada nos séculos seguintes, porque, com o enriquecimento do patriarca, adotaram-se posturas aristocráticas e forjaram-se precursores ilustres:

O fundador da minha família foi um certo Damião Cubas, que floresceu na primeira metade do século XVIII. Era tanoeiro de ofício, natural do Rio de Janeiro, onde teria morrido na penúria e na obscuridade, se somente exercesse a tanoaria. Mas não: fez-se lavrador, plantou, colheu, permutou o seu produto por boas e honradas patacas, até que morreu, deixando grosso cabedal a um filho, o licenciado Luís Cubas. Neste rapaz é que verdadeiramente começa a série de meus avós - dos avós que a minha família sempre confessou, - porque o Damião Cubas era afinal de contas um tanoeiro, e talvez mau tanoeiro, ao passo que o Luís Cubas estudou em Coimbra, primou no Estado, e foi um dos amigos particulares do vice-rei conde da $\mathrm{Cu}$ nha. (ASSIS, 1959, p. 17)

Brás e Brasil compartilham também uma raíz em comum: brasa, cor da madeira que os navegadores lusitanos exportaram para a Europa durante o século XVI, motivo da ocupação dessa parte da América logo após o descobrimento e razão de ser da alcunha atribuída à região dominada por Portugal. O nome "Brasil" não foi, contudo, bem acolhido: a administração metropolitana tinha batizado a nova possessão de Santa Cruz, com a bênção dos religiosos, conforme narra frei Vicente do Salvador: 
O dia em que o capitão-mor Pedro Álvares Cabral levantou a cruz, que no capítulo atrás dissemos, era a 3 de maio, quando se celebra a invenção da santa cruz em que Cristo Nosso Redentor morreu por nós, e por esta causa pôs nome à terra que havia descoberta de Santa Cruz e por este nome foi conhecida muitos anos. (SALVADOR, s. d., p. 15)

Contudo, o nome que ficou foi o outro, para desespero da Igreja e dos padres, que protestaram, pois entendiam o fato como confirmação da presença do demônio no recentemente descoberto e ocupado mundo americano. No seu comentário, o zeloso frade baiano lamenta que, ao invés de se celebrar o lenho sagrado que simboliza o Cristianismo, prestigie-se a madeira que carrega consigo a cor favorita do demônio:

Porém, como o demônio com o sinal da cruz perdeu todo o domínio que tinha sobre os homens, receando perder também o muito que tinham em os desta terra, trabalhou que se esquecesse o primeiro nome e lhe ficasse o de Brasil, por causa de um pau assim chamado de cor abrasada e vermelha com que tingem panos, que o daquele divino pau, que deu tinta e virtude a todos os sacramentos da Igreja (...).

Laura de Mello e Souza resume o fenômeno, conforme o qual a denominação da colônia alegoriza sua situação desviante:

Cristianizando, os portugueses procuravam diminuir as hordas de seguidores do diabo: afinal, o Inferno era aqui. (....) Mas a colônia continuou Brasil, trazendo sempre no nome o estigma infernal que the havia selado o nascimento. (SOUZA, 1995, p. 68)

O nome, sugerido pela tonalidade da lucrativa madeira, sintetiza o Inferno, e essas terras eram diabólicas ao natural, acolhendo degredados, cristãos novos, aventureiros, que se deparavam com uma paisagem luxuriante e índias nuas, provavelmente sedutoras, como notou o competente e observador escrivão Pero Vaz de Caminha:

Ali andavam entre eles três ou quatro moças, bem novinhas e gentis, com cabelos muito pretos e compridos pelas costas; e suas vergonhas, tão altas e tão cerradinhas e tão limpas das cabeleiras que, de as nós muito bem olharmos, não se envergonhavam (ou: não nos envergonhamos). (CAMINHA, 1963, p. 38)

Nenhum nome parecia ser melhor para essa colônia com pendor à depravação; logo, nenhuma personagem poderia deter denominação mais apropriada para representá-la do que Brás Cubas; nenhum lugar poderia ser mais indicado para traduzi-la do que o outro mundo, o subterrâneo e infernal.

O caráter demoníaco do herói não se limita, contudo, à associação suscitada pelo seu prenome, sendo referido com freqüência desde as páginas iniciais do romance, sugerindo que o autor gostaria de ser entendido sob esse ângulo. No capítulo XI, "O menino é o pai do homem", o 
narrador lembra que "merecera (...) a alcunha de 'menino diabo'; e verdadeiramente não era outra coisa; fui dos mais malignos do meu tempo." (ASSIS, 1959, p. 46)

Por sua vez, no capítulo XII, Brás relembra "um episódio de 1814", ocasião em que, numa festa doméstica destinada a comemorar a queda de Napoleão, o narrador, então com nove anos, denuncia os amores de D. Eusébia e o Vilaça, sintoma de sua vilania.

$\mathrm{O}$ incidente pode ser interpretado à luz do livro apócrifo, $A$ vida de Adão e Eva: os dois amantes, ela solteira e ele casado, estão escondidos na chácara, junto a "uma pequena moita" (p. 58), observados apenas pelo pequeno, que ouve o diálogo sedutor do Vilaça e somente interfere após esse beijar a moça; é então que a criança sai a gritar pela casa, revelando o ato incriminador. A chácara não deixa de corresponder ao Jardim do Éden, onde a pequena serpente, outra das imagens consagradas do demônio, se introduz para levar à perdição o casal primordial, representados por Eusébia e Vilaça, de cujo relacionamento nasce Eugênia, seduzida mais tarde por Brás Cubas adulto. ${ }^{4}$

Assim, Brás Cubas pode ser considerado, de um lado, o herói que desce ao Inferno, de onde retorna para narrar suas memórias, compartilhando o conhecimento adquirido com os leitores; nesse sentido, ele reforçaria sua qualificação enquanto herói nacional, cujo aprendizado alcançado durante o percurso ao mundo subterrâneo o habilitaria ao exercício da missão civilizadora. De outro lado, o protagonista do romance pode representar o próprio demônio, governando um mundo devasso e sem perspectivas, figurando alegoricamente a sociedade carioca do século XIX, onde viveu Brás Cubas.

A presença de Virgília reforça qualquer uma das caracterizações, já que a eleição desse nome para batizar a principal personagem feminina do romance não parece ser gratuita. Afinal, Brás Cubas descobre como se chama a noiva escolhida por seu pai, após relembrar e reproduzir os primeiros versos da Eneida, a que se segue a escrita da palavra Virgílio.

O episódio, matéria do capítulo XXXVI, é bastante inverossímil, se encarado sob o prisma da poética realista. Residindo na Tijuca, após a morte da mãe, circunstâncias que acirram sua melancolia, Brás é visitado pelo pai, que o incita a retornar à cidade, aceitar o noiva que elegeu e dedicar-se à política. $\mathrm{O}$ rapaz fica indiferente à proposta do velho Cubas e começa a rabiscar em latim o primeiro verso da Eneida, detendo-se na palavra virumque, a que acrescenta outra, Virgílio. O pai, assistindo à cena, reage:

${ }^{4}$ Devemos a Frieda Liliana Morales Barco a interpretação dessa cena como reprodução da perda do paraíso, conforme narrada no livro apócrifo A vida de Adão e Eva. 
Meu pai, um pouco despeitado com aquela indiferença, ergueu-se, veio a mim, lançou os olhos ao papel...

- Virgílio! exclamou. És tu, meu rapaz; a tua noiva chama-se justamente Virgília. (ASSIS, 1959, p. 110)

A escolha do nome Virgília para a principal personagem feminina do livro já seria suficiente para legitimar a associação entre a obra de Dante e a de Machado de Assis: a moça exerce papel equivalente ao de Beatriz, na epopéia florentina, só que, enquanto esta acompanha o poeta pelo Paraíso, a segunda só pode conduzi-lo pelo Inferno, correspondendo, pois, à versão feminina de Virgílio, guia do narrador de $A$ divina Comédia pelo mundo subterrâneo.

A citação, contudo, acrescenta a essa interpretação um outro dado: o próprio Brás Cubas - “- Virgílio! exclamou. És tu, meu rapaz” - é autor de uma epopéia, expressiva da manifestação do sentimento pátrio e da formação do Estado. Assim, enquanto protagonista da epopéia, Brás é Enéias, síntese da nacionalidade, assim como coincide com o poeta levado pelo Inferno pelas mãos de Virgília; por sua vez, enquanto narrador póstumo das Memórias, ele é o próprio Virgílio. Graças a esse processo, Machado de Assis superou o impasse da epopéia moderna, reintroduzindo a tópica da descida ao mundo subterrâneo, associada à representação de um herói coletivo, síntese da nacionalidade.

Ao fazê-lo, Machado de Assis rearticulou a triangulação importada da Antigüidade, apoiada no tripé tópica da viagem - representação nacional - visita ao mundo subterrâneo. Essa última sempre deteve importância capital para o desdobramento da temática épica: permitia ao herói enfrentar o pior desafio, já que se tratava de cruzar a fronteira entre vivos e mortos e retornar são e salvo; e facultava a introdução da temporalidade, estabelecendo um contraste entre o transcurso horizontal da aventura determinada e corporificada pela viagem - e o trajeto vertical da história, presença imprescindível, dado o objetivo ideológico de propor parâmetros para a identidade nascente de um Estado político, como foi por exemplo a Roma imperial onde viveu e atuou o poeta mantuano.

O Brasil do Segundo Reinado há muito entendia-se desde o paradigma da Roma de Augusto, haja vista a narrativa de José de Alencar, Iracema, construída a partir do mito de fundação da Cidade Eterna. (ZILBERMAN, 1977) País de propensão católica e de sociedade conservadora, o Brasil elegera o regime monárquico e a forma de império, mantendo essa condição à custa da ideologia difundida por escritores e intelectuais do período romântico. Machado de Assis parecia conhecer essas idéias e, embora não tenha aderido ao republicanismo de contemporâneos e amigos seus, como Quintino Bocaiúva, representou-as sob o ângulo da paródia, condensando-as num herói a quem uma grande missão é conferida, sumariada na reunião de Brás Cubas com o pai, no capítulo já citado, mas que ele rejeita e não substitui por qualquer projeto construtivo. 
É nesse sentido que Brás Cubas pode ser entendido como o próprio demônio, príncipe de um império sem perspectivas: embora, como Satã, não experimente culpas e remorsos, ele igualmente não tem salvação. O demônio é o único ser excluído da misericórdia divina, pois, mesmo por ocasião do Juízo Final, a ele caberá o Inferno. Sem alternativas, somente restam as negativas expressas no capítulo derradeiro do livro.

Machado refaz o tema da viagem, produzindo, à sua moda, a epopéia nacional de que o país carecia e que o Romantismo pesquisara, com sucesso relativo, ao se restringir ao Indianismo, rejeitado ainda quando José de Alencar, seu principal adepto e promotor, vivia. Mas a viagem assume teor específico: embora lide com figuras arquetípicas, como quiseram os românticos, seu destino é o submundo, tal qual procederam os clássicos Homero, Virgílio e Dante. O resultado, um blend muito especial, adota a forma da paródia, dessacralizando os paradigmas em que se transformaram os textos inspiradores. Sob esse ângulo, Memórias póstumas converte-se num dos Diálogos dos mortos, partidário também do pessimismo e desesperança veiculados por Luciano. ${ }^{5}$

Machado de Assis foi leitor atento dos clássicos e observador sutil das questões debatidas a seu tempo. Com Memórias póstumas de Brás Cubas, parece enfrentar um dos temas em voga: o que dizia respeito à modelagem de um herói brasileiro, capaz de corporificar a nacionalidade com todos os predicados da desejada cor local. Alcança resultado positivo e, em certo sentido, definitivo, por evocar o aprendizado advindo do conhecimento da literatura do passado, que desvela ao escritor a maneira como se monta, simultaneamente desconstruindo-a, essa figura paradigmática. Deixa, com isso, um legado aos sucessores, como Oswald de Andrade, em Memórias sentimentais de João Miramar, e Mário de Andrade, em Macunaíma, que lhe conferiram tratamento próprio, mas que, como boas maçãs, não caíram longe do pé que os nutriu.

\section{BIBLIOGRAFIA}

ASSIS, José Maria Machado de. Esaú e Jacó. São Paulo, Mérito, 1959a.

ASSIS, Machado de. "Literatura Brasileira - Instinto de nacionalidade". In: . Crítica literária. São Paulo, Mérito, 1959 b.

${ }^{5}$ Enylton de Sá Rego examina, valendo-se do enfoque bakhtiniano, as relações entre Luciano e Machado de Assis. Cf. Cf. REGO, 1989. 
ASSIS, Machado de. "O passado, o presente e o futuro da literatura". In: Obra completa. Rio de Janeiro, Aguilar, 1958.

ASSIS, Machado de. "Prólogo da quarta edição ". Memorias posthumas de Braz Cubas. 4. ed. Rio de Janeiro e Paris, Garnier, 1899.

ASSIS, Machado de. Garrett. In: _ _ Crítica Literária. São Paulo, Mérito, 1959b.

ASSIS, Machado de. Memórias posthumas de Braz Cubas. 3. ed. Rio de Janeiro e Paris, Garnier, 1896.

ASSIS, Machado de. Memorias posthumas de Braz Cubas. Rio de Janeiro, Tipografia Nacional, 1881.

ASSIS, Machado de. Memórias póstumas de Brás Cubas. São Paulo, Mérito, 1959.

BENJAMIN, Walter. "O narrador. Considerações sobre a obra de Nikolai Leskov." In: . Obras escolh idas. Magia e técnica, arte e política. Trad. de Sérgio Paulo Rouanet. São Paulo, Brasiliense, 1985.

BLOOM, Harold. Presságios do milênio. Anjos, sonhos e imortalidade. Rio de Janeiro, Objetiva, 1996.

CAMINHA, Pero Vaz de. Carta a El Rei D. Manuel. Introdução do texto, glossário, bibliografia e índices por Leonardo Arroyo. São Paulo, Dominus, 1963.

DELUMEAU, Jean. História do medo no Ocidente. 1300 - 1800. São Paulo, Companhia das Letras, 1990.

ELIADE, Mircea. Mefistofeles y el Androgino. Madri, Guadarrama, 1969.

GARRETT, Almeida. Viagens na minha terra. São Paulo, Difusão Européia do Livro, 1965.

ISIDORO de Sevilha. Etimologías. Madri, Biblioteca de Autores Cristianos, 1951.

LANGTON, Édouard. La Démonologie. Étude de la doctrine juive et chrétienne, son origine et son développment. Paris, Payton, 1951.

LINK, Luther. O Diabo. A máscara sem rosto. São Paulo, Companhia das Letras, 1998.

REGO, Enylton de Sá. O calundu e a panacéia. Machado de Assis, a sátira menipéia e a tradição luciânica. Rio de Janeiro, Forense Universitária, 1989.

SALVADOR, Frei Vicente do. História do Brasil. 3. ed. Revista por Capistrano de Abreu e Rodolfo Garcia. São Paulo, Melhoramentos, s. d.

SOUZA, Laura de Mello e. O Diabo e a Terra de Santa Cruz. Feitiçaria e religiosidade popular no Brasil colonial. 5 reimpressão. São Paulo, Companhia das Letras, 1995.

ZILBERMAN, Regina. Do mito ao romance. Tipologia da ficção brasileira contemporânea. Porto Alegre, Escola Superior de Teologia; Caxias, Universidade de Caxias do Sul, 1977. 